\title{
The Urgency of Multicultural Education for Children
}

\author{
Slamet Slamet", Maria Agustiningrum, R. Soelistijanto, Dwi Asih Kumala Handayani, \\ Eko Heri Widiastuti, Banun Sri Hakasi
}

Faculty of Teacher Training and Education Science, Universitas Ivet, Semarang, 50233, Jawa Tengah, Indonesia

Received September 28, 2020; Revised December 15, 2020; Accepted January 20, 2021

\section{Cite This Paper in the following Citation Styles}

(a): [1] Slamet Slamet, Maria Agustiningrum, R. Soelistijanto, Dwi Asih Kumala Handayani, Eko Heri Widiastuti, Banun Sri Hakasi , "The Urgency of Multicultural Education for Children," Universal Journal of Educational Research, Vol. 9, No. 1, pp. 60 - 66, 2021. DOI: 10.13189/ujer.2021.090107.

(b): Slamet Slamet, Maria Agustiningrum, R. Soelistijanto, Dwi Asih Kumala Handayani, Eko Heri Widiastuti, Banun Sri Hakasi (2021). The Urgency of Multicultural Education for Children. Universal Journal of Educational Research, 9(1), 60 - 66. DOI: 10.13189/ujer.2021.090107.

Copyright $\bigcirc 2021$ by authors, all rights reserved. Authors agree that this article remains permanently open access under the terms of the Creative Commons Attribution License 4.0 International License.

\begin{abstract}
Multicultural education is also interpreted as a social policy based on the principles of preservation of culture and mutual reverence between all cultural groups in a society. Basically, multicultural education is a national education program that multicultural community can participate in creating a democracy that is ideal for the nation. The study design was research and development while adapted the design of the models by McKenny. The research procedure was based on 10 drafts from Borg and Gall, which then were modified into 3 phases, namely: 1) Preliminary studies conducted at schools in Central Java-Indonesia; 2) development of multicultural learning designs a design development; and 3) testing the feasibility of multicultural learning products. The findings of this study state that the implementation of multicultural education can be carried out through curriculum at every level of education, student program and habituation in the daily learning process both in the school and family environment. The insertion of multicultural education can be carried out through planting the values of multiculturalism into the curriculum or learning activities which are responsive to promote respect for diversity: racial, ethnic, cultural, religious, and territorial between citizens and more importantly, the discourse of value of local wisdom education can be implemented within the scope of a family as the smallest social institution.
\end{abstract}

Keywords Multicultural Education, Children

\section{Introduction}

The definition of multicultural education includes experiences that shape public perception of religion, social status, cultural identity, language, race, ethnicity, and territorial [1]. Multicultural education is an idea and a movement of educational reform and the process that aims to change the structure of educational institutions and family so that students as members of racial, ethnic, religious, territorial, and diverse cultures have equal way of looking at the life of Indonesia as a nation.

Indonesia compared with other countries is a country that is not only multi-ethnic in terms of ethnicity, religion, and region, but also multi-cultural. Pluralism on the one hand is a social force and diversity is beautiful when in synergy with each other and work together to build the nation. On the other hand, a plurality if not managed and nurtured wisely, can trigger conflict and violence that could destabilize the joints life of the nation. The conflict in Ambon and Poso, for example, is an example of the violence and the conflict that has been draining and detrimental not only to the spirit and material, but also the expense of harmony among members of society and Indonesia. Here, discourse and implementation of multicultural values find its place, which means that multicultural education becomes an important factor [2].

Multicultural education is also an educationto respect differences. Multicultural education is always creating structures and processes in every culture to be able to perform expression. Therefore, a way to design the multicultural education is needed in practice. But the reality is not easy, it is necessary to design concepts in 
accordance with the principles of multiculturalism. At least there is no concept for realizing the multicultural education that gives a space of freedom for the citizens (= student) expression, including the dialogue. Multicultural education may not be embedded in the learners well when there is an absence of dialogue. In multicultural education, each civilization and multicultural values include diversity like race, religion, language, culture, gender, and territories are in a parallel and equal position. No multicultural values which are considered better and higher as the superior of multicultural values like race, religion, language, culture, race, and area of other tribes [3].

In dialogue, equality is inevitable between the parties involved. The assumption that the basic values of a particular multicultural ishigher than other cultures would give birth to Fascism, nativism, and chauvinism. In addition, the dialogue will create discordant thoughts which in turn will enrich the cultural values and civilization for the people concerned. Dialog also functions as enrichment, even very important to find common ground between the values of culture and civilization there. Multicultural education can be defined as a form of awareness about the diversity of cultures, human rights, and reduction/ elimination of various types of prejudice higher than multicultural values to build a successor to the lives of young people as a nation-state.

Education that contains multicultural values is the stages of an educational process that can be used as a binder and a bridge to accommodate differences, such as ethnicity, language, ethnic, cultural, regional, gender and religion in a multi-cultural society in order to create the personality of intelligent, wise and courtesy in dealing with diversity issues [4]. Multicultural education also needs to continue to do this approach in a comprehensive manner, so that it will not merely be a discourse, but it will ultimately be implemented in harmony and without any negative consequences. This basis makes the urgency for immediate implementation of multicultural education in educational institutions, so we need a comprehensive study covering various aspects and aspects of life so that there is synergy between the academic community and the community nation-wide in the country [5].

\section{Methods}

This study employs a research and development (R\& D) design introduced by Borg and Gall and another design of the procedural model developed by McKenny. The procedure of this study is based on ten schemes of Borg and Gall [6], which has been modified into three phases, namely: 1) preliminary studies; 2) development of the design; and 3) testing the feasibility of the product.

The preliminary studies have been done by spreading instruments on needs to 35 high school history teachers in the district of Kudus. The design of the training management model of developing materials containing multicultural values (PBA-BNM) was based on a literature review, the results of a preliminary study on the training of learning materials development over the years, and the needs analysis of the training expected by high school history teachers. The study of literature for this research includes the current study of training management for high school history teachers which was considered as the referential framework for the development of the training management model of materials development containing multicultural values to be implemented in the learning processes at school.

The planning stage carried out in the development of training models includes 1) identification of needs; 2) setting goals; 3) development program; 4) development of materials; 5) development of evaluation tools; and 6) developing guidelines and training manuals. The training organization phase consists of the following activities: 1) personnel organization; 2) formulating a training management task; 3) specifying the requirements for trainees; and 4) obtaining procedures and working mechanisms. The PBA-BNM training phase was implemented by means of face to face interaction, including 1) preparation; 2) pre-training activities; 3) implementation of the training; and 4) the final activity of training/evaluation. The evaluation phase of training is conducted before, whilst, and after training. The development of training evaluation device consists of 1) the evaluation prior to training or pre-test; 2) program evaluation; 3) instructor evaluation; and 4) evaluation of training participants. Meanwhile, the product feasibility is assessed by three experts: 1) expert/specialist in material development training; 2) experts/specialists in educational management; and 3) an experts/specialists in history and multicultural education.

Data about the condition and needs of the training model was analyzed using a descriptive percentage technique, evaluated using the Likert scale questionnaire that has been modified. The closed questionnaire was analyzed using mean analysis techniques. Data from the open questionnaire and recording of the focused group discussion (FGD) were analyzed using qualitative descriptive analysis techniques.

\section{Results}

The results of this research and development can be seen from the three perspectives, i.e. ontological, epistemological, and axiological. Ontologically, multicultural values implant a caring attitude, wanting to understand the recognition of minority groups as part of a wider community. With the basic view which is not only rooted in the structure of racial inequality, the multicultural education paradigm respects all elements of society in Indonesia, such as those of ethnic, racial, social, territorial, 
religious, cultural, and language. This kind of paradigm encourages the growth of research on ethnic studies which in turn will find a place as a forum of curriculum containing multicultural values from early childhood education up to higher education.

However, based on the instruments of teachers' needs, the training management model of material development for teachers has been implemented poorly. This is due to 1) During planning, need analysis is only done on a group of teachers in MGMPs and the material does not correspond with the competencies expected by the teachers; 2) the training instructors are merely among teachers who are not professional in their field; 3) the planning, organizing, and evaluation of the training programs rely heavily on the local education office program so that the program created often cannot be implemented; 4) The training facilities are not in accordance with good training standards; and 5) there is no follow up activity in training.

Epistemologically, through these activities, it is believed that training based on the activity needs will result in new knowledge. The training management model of material development was developed on the basis of data from actual conditions during the training that was conducted, literature review, research results, and training needs analysis for high school history teachers. Among them are as follows. (1) Based on the training needs questionnaire it was known that the training needs of materials development for high school history teachers are very high; (2) The results of the needs analysis, a training model of material development charged with multicultural values for teachers in Indonesia. It was eligible to apply. Currently, the teaching materials expected by high school history teachers are effective, in the sense of easily understood and implemented. The early form of training management model developed includes 1) planning analysis (requiring 3 steps); 2) organization (3-steps planning); 3) implementation (2-step development and 4-step implementation); and 4) evaluation (3 steps). The level of accuracy of the conceptual training management model of material development charged with multicultural values for high school history teachers is considered being valid, after the limited try-out to 35 high school history teachers in Kudus regency of Central Java province.

Axiologically, this study was associated with the study of the values or dignity and actions in the training activities, in order to obtain the form or the training model. The final form of the development of the training management model of material development charged with multicultural values for high school history teachers is a model resulted from the development that has been validated by experts/specialists and has been tested through the individual test, group test, and limited test. The final form of the training management model of material development charged with multicultural values for high school history teachers. Based on the limited test results it was found that the training management model PBA-BNM was feasible because it has a level of effectiveness.

\subsection{The Development of Multicultural Education}

[7] explain that in its development, the curriculum that uses a multicultural approach should be based on the following principles: 1) cultural diversity is the basis in determining the philosophy, theories, models, and the schools relationship with local socio-cultural environment; 2) cultural diversity becomes the basis for the development of various components of the curriculum such as: objectives, content, process, and evaluation; 3 ) the culture in the education unit is a source of learning and study objects that should be part of the activities of learners; and 4) the curriculum has a role as the media in developing regional culture and national culture.

[8] suggested that the 7 (seven) stages are considered in the development of multicultural education-based curriculum.

1. Defining the vision, mission, goals of the school, and personal development that reflects the multicultural curriculum based school.

2. Assessing Competence Standard and Basic Competence which contains multicultural values, with regard to the following matters: (1) the urgency of the lives of young people associated with multiculturalism; (2) the relationship between the standard of competence and basic competences in other subjects that includes multicultural; (3) relevance to the needs of learners in a multicultural society; and (4) the benefits or meaningfulness for learners in their daily activities.

3. Identify the Learning Materials which contains Multicultural values, taking into account the following matters: (1) the diversity of learners; (2) characteristics of the subjects; (3) the relevance of the area characteristics; (4) the level of physical, intellectual, emotional, social, and spiritual developments of the learners; (5) the usefulness for learners; (6) the actuality of learning materials; and (7) The relevance to learners' needs and demands of the environment.

4. Develop Learning activities that contains Multicultural values

The learning activities are designed to provide a learning experience that involves mental and physical processes through interaction between learners, learners with teachers, environment, and other learning resources in order to achieve basic competence. The learning activities are intended to be realized through the use of inquiry learning approaches and learner-centered method, as well as by applying some relevant learning methods. The thing that must be considered in developing learning activities with multicultural values are: (1) multicultural learning activities are organized to provide assistance to educators in order to implement the learning process in a professional 
manner; (2) multicultural learning activities includes a series of activities that must be carried out by learners; (3) in determining the sequence of learning activities, remember that it must be in accordance with the learning material with multicultural values; and (4) the formulation of the statement in the learning activities are with multicultural values contains at least two elements, namely the activities of learners and multicultural materials.

1. Formulate the competence achievement indicators withmulticultural values

Indicators which contain multiculturalism is a marker of basic competence achievement which is characterized by behavioral changes that can be measured including the attitudes, knowledge, and skills with multicultural values. Indicators were developed in accordance with the characteristics of learners, subjects, educational units, the environment and potential areas defined in the measurable and/ or observable operational verb. Indicators are used as a basisto draw up an assessment tool.

2. Determiningthe assessment system with multicultural values

Asessing the achievement of basic competencies with multicultural values for learners is based on the indicators with multicultural values. Assessment is done by using the test and non-test in the form of written or oral assessment, observation of performance, attitude measurement, assessment of the work in the form of assignments, projects and/ or products, the use of portfolios, and self-assessment. Assessment based on the values of multiculturalism is a series of activities to acquire, analyze, and interpret data about the process and the learning outcomes of students who carried out systematically and continuously so that it becomes a meaningful information in decision making.

3. Determine the Learning Resources with Multicultural Values

Learning resources are references, objects and/ or materials with multicultural values that are used for learning activities, such as print and electronic media, sources, and physical, natural, social, and cultural environment. Pinpointing the source of learning with multicultural values based on the standards of competence and basic competencies and learning materials, learning activities, and indicators of achievement of competencies.

\subsection{The Urgency of Multicultural Education Model}

Referring to the population census by the Central Statistics Agency (BPS) in 2010, Indonesia has around 1,340 ethnic groups, 5 religions and 187 faiths. As a heterogeneous or compound nation, multiculturalism becomes very important to be developed, then the programs are always directed to foster multicultural understanding and participation of community groups in order to grow sympathetic behavior to the struggle of the multicultural, especially multicultural education for children [9].

The steps needed are as follows: (1) multiculturalism needs to be part of the educational curriculum. Multicultural dimension should be reflected in other subjects: civics education, geography, literature, history, politics and economics. Religious and moral education needs to introduce the reality of plurality, without reducing it into relativism, it will be better when the followers of the religion are the ones who give explanation; (2) in the public sphere, the multicultural dimension needs to be encouraged not only in the form of politics, but also in the expression of art, theater, music and film; (3) need to develop a program that allows guaranteed representation of minorities in politics, education, and employment; and (4) the government should encourage managers of mass media such as radio, television, newspapers, magazines and the internet to pay attention and have concern for multicultural values.

Other forms of creativity that is needed is to intensify the encounter and dialogue. Multicultural policies usually disturb the establishment of the majority who already enjoy privileges as the dominant group. The reason is that multiculturalism has implications for political representation, culture, employment and education. The majority's first reaction is usually disqualifying multicultural valuesin order to maintain hegemony and interests and their supporters. The understanding that cultural groups and powerful minority will be able to empower civil society does not fit in the perspective of the opponents of multiculturalism [10].

The model of education in Indonesia and in other countries shows the diversity of interest, strategy and the means used to achieve it. Some critics view that revision of school curriculum is done in multicultural education programs in the UK and some places in Australia and Canada, is limited to cultural diversity, so they were limited to the cognitive dimension.

The addition of information on cultural diversity is a model of multicultural education that includes revisions or instructional materials, including the revision of textbooks. Apart from the criticism of its implementation in some places, such as the revision of learning in the United States is considered the most important strategies in education and curriculum reform. Rewriting the American history from a more diverse perspective as an education agenda championed intellectuals, activists and practitioners. In Japan there are serious humanitarian activists advocating to revise the history books, especially concerning the role of Japan in World War II in Asia. Although it has not been accepted, this business has started to open the eyes of some people about the importance of new perspectives on the war, so that the humanitarian tragedy does not happen again. While Indonesia still needs a long effort to revise the textbooks in order to accommodate the contribution and participation that is more inclusive for people of all backgrounds in the formation of Indonesia. 
Another model is that multicultural education does not merely revise the learning material but to reform the system of learning itself. Affirmative action in the selection of students to teacher recruitment in America is one of the strategies to make improvements to structural imbalances against minorities. Another example is the "schools intermingling" model of Iskandar Muda school in Medan, which facilitates the interaction of learners from different cultural backgrounds and arrange foster care programs across groups. In the United States in conjunction with the entry of the discourse of multiculturalism, various workshops are conducted in schools and in the wider community to increase social sensitivity, tolerance and reduce prejudices between groups. To realize these models, multicultural education in Indonesia need to use a combination of the existing models, in accordance with Gorski's suggestions, multicultural education can include three transformations, namely: (1) the transformation of self, (2) the transformation of schools and learning process; and (3) the transformation of society.

\subsection{Multicultural Education Service}

Multicultural education is very important for the citizens of Indonesia since the previous explanations have raised confidence how the paradigm of multicultural education is very useful to build cohesiveness, solidity and intimacy between the diversity of ethnicity, race, religion, culture, and region of learners. The exposure also gave encouragement and spirit for educational institutions nationwide to want to invest their attitude to learners to appreciate people, culture, ethnicity, religion, region, and other beliefs [11]. Hopefully, with the implementation of education with multicultural values, it will help learners to understand, accept and respect other people of different ethnicity, culture, religion, region, and the value of personality. Through the cultivation of the spirit and multicultural values in schools, it will be the medium of training and awareness for young people to accept cultural differences, religious, racial, ethnic, regional, and needs among others and want to live together peacefully. In order for this process to run as expected, then the students should be able toaccept if multicultural education will be promoted and disseminated through educational institutions, as well as (if possible) set up as part of the educational curriculum at all levels both in public and private educational institutions. Moreover, multicultural paradigm implicitly also become the concern of Article 4 of Law No. 20 Year 2003 on National Education System. The article described; education is held democratically, not discriminatory to uphold human rights, religious values, cultural values and diversity of the nation.

In this context it can be said that the main objective of multicultural education is to inculcate an attitude of sympathy, respect, appreciation and empathy for the followers of different religions and cultures. Furthermore, faiths and different cultures can learn to fight or at least do not agree with intolerance like inquisition (a state court on a legitimate either theological or ideological), a religious war, discrimination, and cultural hegemony in the midst of culture monolithic and global uniformity.

Historically, multicultural education as a concept or idea does not appear in the empty room, but there are political, social, economic and intellectual interests which encourage its emergence. Multicultural education discourse at first was very biased, because the Americans have historical roots with the human rights movements of the various oppressed groups in the country [12]. Many tracing the history of the origins of multicultural education that refers to the social movement of African Americans and other colored-skin groups who experienced discriminatory practices in public institutions in the struggle for human rights in the 1960s [13]. Among the institutions that are specifically highlighted as hostile to the idea of racial equality at the time it is educational institutions. In the late 1960s and early 1970s, the voices demanding educational institutions to be consistent in accepting and respecting differences louder, echoed by activists, leaders and parents. They have demanded equality of opportunity in jobs and education. Momentum is considered as the beginning of the conceptualization of multicultural education.

Generic, multicultural education is a concept created with the aim to create equal educational opportunities for all learners of different race, ethnicity, social class, religion, region, and cultural groups. One important goal of the concept of multicultural education is to help all learners to acquire the knowledge, attitudes and skills required in running roles effectively in the democratic-pluralistic public and required to make interaction, negotiation, and communication with the citizens of a diverse groups to create a moral order of society that goes for the common $\operatorname{good}[14]$.

In the implementation, the paradigm of multicultural education are required to adhere to the following principles: (1) multicultural education must offer a diverse curriculum that represents the views and perspectives of many people; (2) multicultural education should be based on the assumption that there is no single interpretation of the historical truth; (3) The curriculum is achieved in accordance with the emphasis on comparative analysis of the viewpoints of different cultures; (4) multicultural education must support the basic principles in combating stereotypes about race, culture, ethnicity, territoriality, and religion. Multicultural education reflects a balance between understanding the similarities and differences in cultures as well as encourages individuals to maintain and expand the horizons of their own culture and custom.

Some aspects are key to implementing multicultural education within the school structure is the absence of policies that impede tolerance, including the absence of an insult to race, ethnicity, religion, region, culture, and gender. Also must develop a sensitivity to cultural 
differences, among which include clothes, music and favorite foods. Moreover, it also provides the freedom for students in celebrating the great days of religious communities and strengthening the children's behavior in order to feel the need to engage in democratic decision making.

\section{Discussion}

Key Points of Multicultural Education for Children is to realize multicultural education for children, which is done in the following steps: (1) Preparing the materials or curriculum for children that glorifies the cultural differences; (2) Set up a curriculum for children that studies of other local cultures ranging from traditional dance, literature, handicrafts other tribes in Indonesia and others [15]; (3) Set up a curriculum for children that is not discriminatory to uphold human rights, religious values, cultural values, local wishdom value and diversity of the nation; (4) Prepare materials for children based on moral values to instill respect for people, culture, religion, region, and other faiths; (5) Build a monument and museum in each region to serve the area of cultural studies and can be used as additional reference materials to the subject matter; (6) Create jobs that are possible to produce handicrafts that characterizes the culture of the region; (7) Equity in multicultural education for schools from both government and private educational institutions and even for the international schools, namely early childhood education which has its own curriculum which refers to the curriculum of other countries which previously laid a multicultural foundation in the field of education; (8) Equality in multicultural education for all children regardless of differences in race, religion, social status and ethnicity; (9) Development of children's potential to develop social skills and knowledge of local wisdom values with advances in science and technology; and (10) to accelerate the process of getting the patent of all cultural productsthat is not claimed by another country and so forth. Things like the above can not be separated from the interference of the government in order to run smoothly and bring positive results and can bring good impact and progress for Indonesia.

The role of Pancasila, state ideology of Indonesia, should be able to quell conflicts, particularly in multicultural issues. The bloodshed should not happen, many examples of the events that occur in Indonesia as a result of their wide variety of bloody conflict in Sampit between Dayak and Madurese, bloody conflict in Maluku between Moslems and Christians, and various examples of bloody conflict and other actions that have been incised havewounded this country. Thus, they are some of the known impact that would occur if the multicultural education is not immediately used as one of the subjects in school, because the previous material of multicultural education only as a chapter or review material in a school subject, for example: civic education, religion, and history.

Multicultural educational strategy should be applied in school subjects by integrating cultural differences that exist in students background, such as ethic differences in language, race, gender, ability, religion [16]. Multicultural education should be taught to children from an early age in kindergarten and the level of higher education, for multicultural education will provide a better impact for Indonesia. From an early age, learners will learn more about the culture of each and will also get to know the culture of other tribes in Indonesia so that disputes between tribes can be replaced with an attitude of mutual respect and, more importantly, to avoid the claims of other countries that recognize one Indonesian culture as a culture, such as batik and reog which has been claimed by Malaysia as its culture, and tempe from Malang which has been claimed by Japan as their special food. Therefore, the importance of multicultural education for Indonesian citizens who are full of national culture according to the proverb: "Other fields of other locusts, another bottom of the other fish," so that there will not be any conflict that will make Indonesia disappointed and even embarrassed because most of the population does not know its own culture.

\section{Conclusions}

As a pluralistic country, Indonesia needs to develop the concept of multicultural education as a foundation for strengthening national identity. The results of this study prove that through multicultural education it can be a way for the emergence of conflict and disharmony that occurs in society related to differences in race, ethnicity, religion and culture, especially frequent in Indonesian society that is pluralistic. In other words, multicultural education can be an alternative means of solving social conflicts in the culture of a nation.

The spectrum of Indonesian society's diverse culture becomes a challenge for education in order to cultivate these differences into an asset rather than a source of division. Currently multicultural education has two major responsibilities, namely to prepare the nation to be ready to face the flow of foreign cultures in the era of globalization, and to unite the nation itself which consists of various cultures.

Multicultural education is a progressive approach to education transformation that thoroughly dismantles the shortcomings, failures and discriminatory practices in the education process. Multicultural education is very important to be developed, then the programs are always directed to foster multicultural understanding and participation of certain groups in order to grow the sympathetic attitude to multicultural struggle itself.

Multicultural education is based on the idea of social 
justice and equality in education. While in religious doctrine, in fact do not discriminate ethnic, racial, religion, linguistic, cultural, territorial and others. Multicultural education is also considered important in order to bridge the different interests and characters in local education. Different interests are one of the constraints of national education development for more than half a century. With the development of this multicultural education model focusing on respecting the value of local wisdom so that it is expected to be an effective method to reduce conflicts that arise in Indonesian society. In addition, through multicultural education children will learn to really respect differences in ethnicity, race, religion, culture, language, and the surrounding areas and learn to make them a force for progress.

\section{REFERENCES}

[1] Banks, James. (2007). Race, Culture, and Education: The Selected works of James A. Banks.

[2] Slamet, etc. (2017) The Implementation of Multicultural Values in The Educational Institution. The Journal of Educational Development. 5 (1), 118-127

[3] Parekh, Bhiku. 2008, Rethinking Multiculturalism: Keberagaman Budaya dan Teori Politik, Yogyakarta: Kanisius.

[4] Agustiningrum, Maria. (2019). Stimulation of Social-Emotional of Children's Digital Natives Through Learning Nawung Sekar Dance. Golden Age. 3 (2). 41-47.

[5] M. Sahal and Akhayar. (2018). Tolerance in Multiultural Education: A Theoretical Concept. It, journal
Multireligious Understanding., 16 (4). 115-122.

[6] Sugiyono. (2012) Metode Penelitian Kuantitatif, Kualitatif dan R\&D, Bandung: Alfabeta.

[7] Naim, Ngainun dan Sauqi, Achmad. (2011). Pendidikan Multikultural: Konsep dan Aplikasi, Jogjakarta: Ar-Ruzz Media.

[8] Parmono, Eko Sarwito. (2001). Kesalahan Konsep Pembelajaran Sejarah. Jurnal Paramita. 2 (9). 11

[9] Agustiningrum Maria. (2014). Penanaman proses pendisplinan diri anak berkebutuhan khusus (tuna rungu wicara) dalam pembelajaran tari tradisional. Cakrawala Dini. 5 (1). 31-39.

[10] Tilaar, H.A.R. (2004). Multikulturalisme: Tantangan-tantangan Global Masa Depan dalam Transformasi Pendidikan Nasional. Jakarta: Grasindo.

[11] Slamet. (2012) Pelayanan Akademik Mahasiswa. Jurnal Manajemen Pendidikan: 7(2). 35-42.

[12] Slamet. (2016) Penerapan Nilai-nilai Multikultural dalam Institusi Pendidikan. Jurnal Pawiyatan. 23(1),

[13] Susiati, Titik. (2016). Pendidikan Karakter: Salah Satu Alat Pemersatu Bangsa. Jurnal Pawiyatan. 23(1)

[14] Rachmadtullah R, Syfyan Harlinda, Rsmitadila. (2020). The Role of Civic Education Teachers in Implementing Multicultural Education in Elementary School Students. Universal Journal of Educational Research. 8 (2). 540-546.

[15] Agustiningrum Maria. (2019). Stimulation of Social-Emotional of Children's Digital Natives Through Learning Nawung Sekar Dance. Golden Age. 3 (2). 41-47

[16] Tonbuloglu B, D. Aslan and H. Aydin. (2016). Teachers Awareness of Multicultural Education and Diversity in Shool Settings. Eurasian Journal res. 16 (64). 1-28. 